\title{
PENGARUH PENEMPATAN PEGAWAI, FASILITAS DAN KOMITMEN TERHADAP MOTIVASI KERJA PEGAWAI BADAN PENGELOLA KEUANGAN, PENDAPATAN DAN ASET DAERAH KOTA TANJUNGBALAI
}

\author{
${ }^{1}$ Herianti Sirait, ${ }^{2}$ Dewi Sitio, ${ }^{3}$ Muhammad Ichsan Prawira \\ ${ }_{1,2,3}$ Universitas Islam Sumatera Utara \\ ${ }^{1}$ herianti.sirai@gmail.com, ${ }^{2}$ dewi.siti@gmail.com, ${ }^{3}$ Ichsan.prawira@gmail.com,
}

\begin{abstract}
The formulation of the problem in this study is whether the placement of employees, facilities, and commitment simultaneously has a positive and significant effect on the work motivation at Regional Financial Management, Income and Assets Agency, Kota Tanjungbalai. This study aims to determine the effect of employee placement, facilities and commitment to work motivation at Regional Financial Management, Income and Assets Agency, Kota Tanjungbalai. The sample in this study were all employees at Regional Financial Management, Income and Assets Agency, Kota Tanjungbalai, which numbered 46 people. The data analysis technique in this research is Multiple Linear Regression. The results of this study indicate; Employee placement partially has a positive and significant effect on employee motivation; Facilities partially have a positive and significant effect on employee motivation; Commitment partially has a positive and significant effect on employee motivation; Employee placement, facilities and commitment simultaneously have a positive and significant effect on employee motivation.
\end{abstract}

Keywords : Employee Placement, Facilities and Commitments; Work Motivation

ABSTRAK : Rumusan masalah dalam penelitian ini apakah penempatan pegawai, fasilitas, dan komitmen secara simultan berpengaruh positif dan signifikan terhadap motivasi kerja pegawai Badan Pengelola Keuangan, Pendapatan dan Aset Daerah Kota Tanjungbalai. Penelitian ini bertujuan untuk mengetahui pengaruh penempatan pegawai, fasilitas dan komitmen terhadap motivasi kerja pegawai Badan Pengelola Keuangan, Pendapatan dan Aset Daerah Kota Tanjungbalai. Sampel dalam penelitian ini adalah seluruh pegawai Badan Pengelola Keuangan, Pendapatan dan Aset Daerah Kota Tanjungbalai yang berjumlah 46 orang. Teknik analisis data dalam penelitian ini adalah Regresi Linier Berganda. Hasil penelitian ini menunjukkan; Penempatan pegawai secara parsial berpengaruh positif dan signifikan terhadap motivasi kerja pegawai; Fasilitas secara parsial berpengaruh positif dan signifikan terhadap motivasi kerja pegawai; Komitmen secara parsial berpengaruh positif dan signifikan terhadap motivasi kerja pegawai; Penempatan pegawai, fasilitas dan komitmen secara simultan berpengaruh positif dan signifikan terhadap motivasi kerja pegawai.

Kata Kunci: Penempatan Pegawai, Fasilitas Dan Komitmen; Motivasi Kerja

\section{Pendahuluan}

Motivasi kerja ialah faktor pendorong atau daya penggerak untuk bekerja bagi pegawai dalam sebuah organisasi. Motivasi kerja dapat memacu pegawai untuk bekerja keras sehingga dapat meningkatkan produktifitas kerja pegawai dan akan berpengaruh pada pencapaian tujuan organisasi.

Motivasi merupakan hal yang sangat penting untuk diperhatikan oleh pihak organisasi bila menginginkan setiap pegawai dapat memberikan andil positif terhadap pencapaian tujuan organisasi, karena dengan motivasi seorang pegawai akan memiliki semangat yang tinggi dalam melaksanakan tugas dan tanggung jawabnya.

Pentingnya motivasi karena motivasi adalah hal yang menyebabkan, menyalurkan, dan mendukung perilaku manusia supaya mau bekerja giat dan antusias mencapai hasil yang optimal. Oleh karena itu, agar setiap pegawai mempunyai motivasi kerja yang tinggi, perlu 
bagi organisasi untuk memberikan motivasi kepada pegawainya. Dalam pemberian motivasi setiap organisasi memberikan motivasi yang bervariasi, misalnya kepuasan kerja seorang pegawai, lingkungan tempat bekerja, pemberian kesempatan untuk maju dan lain sebagainya. Hal ini dimaksudkan agar kebutuhan pegawai dapat terpenuhi, sehingga diharapkan para pegawai akan merasa tenang dalam bekerja dan mentaati peraturan yang telah ditetapkan, saling menghargai hak dan kewajiban dan dapat memberikan disiplin kerja yang tinggi. Disiplin sangat membentuk suasana kerja yang baik dimana pegawai mematuhi dan mentaati normanorma peraturan yang ada dalam organisasi karena dengan tingkat disiplin yang tinggi yang dimiliki oleh setiap pegawai dapat menunjang dalam usaha mencapai tujuan yang telah ditetapkan.

Sehubungan dengan peran, fungsi dan kedudukan Aparatur Sipil Negara (ASN), sangat menentukan sukses atau tidaknya program pembangunan. Oleh karena itu, kepadanya perlu diberikan motivasi demi mencapai produktivitas kerja yang tinggi demi suksesnya program pembangunan nasional. Disamping itu, para pengelola pembangunan tidak hanya memerlukan pengetahuan dan keahlian dibidang ekonomi, politik, sosial dan teknologi, namun juga di tunjang administrasi yang baik dalam perencanaan maupun dalam pelaksanaannya. Rencana kebijaksanaan yang bagaimanapun idealnya, juga tidak disertai dengan kemampuan dan keterampilan aparat, maka akan cenderung mengalami kegagalan. Dengan demikian, dapat dikatakan sukses atau tidaknya kegiatan pemerintah dan pembangunan, sangat ditentukan oleh kemampuan dan motivasi kerja pegawai.

Berdasarkan pengamatan awal penelitian di Badan Pengelola Keuangan, Pendapatan dan Aset Daerah Kota Tanjungbalai diindikasikan ada beberapa masalah yang menyebabkan menurunya motivasi kerja di instansi tersebut. Hal ini bisa dilihat dari hasil persentase kehadiran berbanding dengan realisasi kerja yang dapat dilihat pada tabel dibawah ini.

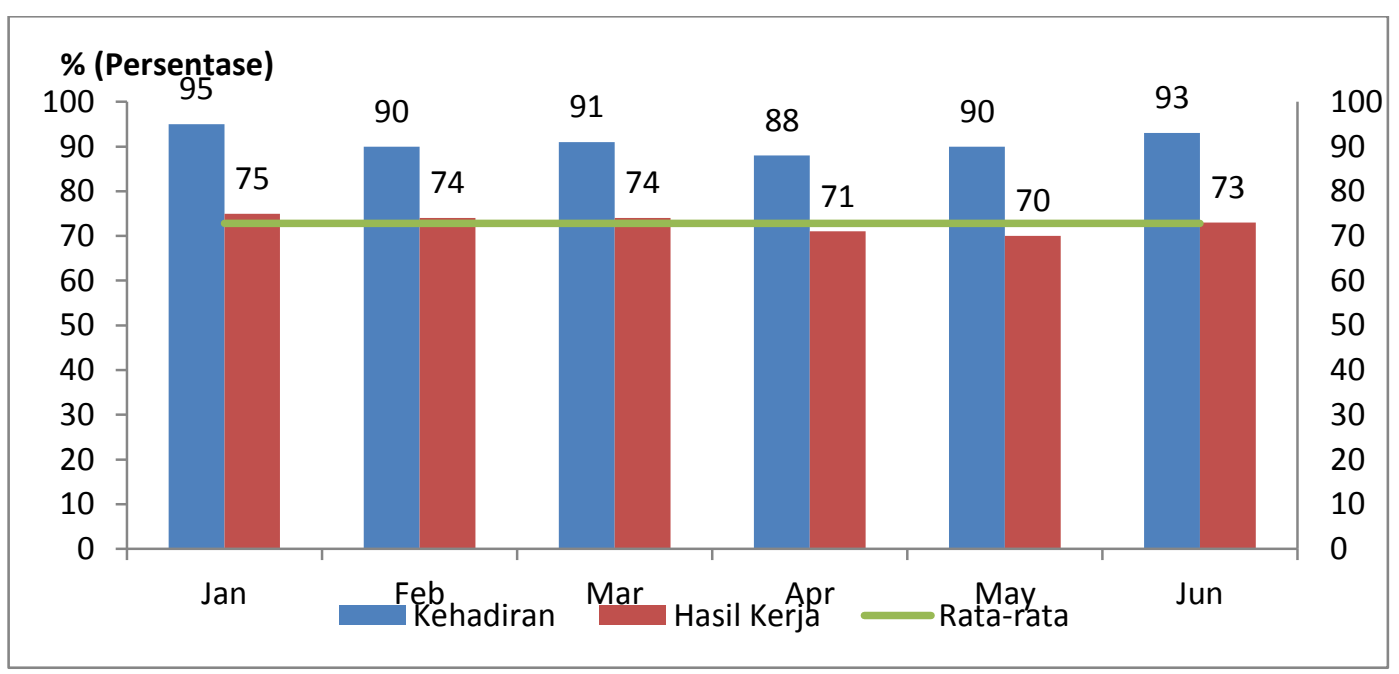

Gambar 1. Persentase Kehadiran dengan Realisasi Kerja

Sumber: Badan Pengelola Keuangan, Pendapatan dan Aset Daerah Kota Tanjungbalai,-2020

Rendahnya realisasi kerja yang hanya mencapai $72,8 \%$ tetapi berbanding terbalik dengan tingkat kehadiran yang baik di Badan Pengelola Keuangan, Pendapatan dan Aset Daerah Kota Tanjungbalai. Hal ini menunjukkan ada permasalahan dengan motivasi kerja pegawai Badan Pengelola Keuangan, Pendapatan dan Aset Daerah Kota Tanjungbalai. Dari egamatan awal oleh peneliti, ada beberapa permasalah yang dirasakan mempengaruhi rendahnya motivias kerja pegawai yang tertuang dari realisasi kerja yang masih kategori cukup.

1) Tentang penempatan posisi kerja pegawai yang dirasa sebahagian kurang tepat sasaran atau kurang sesuai dengan kemampuan dan latar belakang pendidik pegawai

2) Fasilitas kerja yang ada pada kantor untuk kegiatan kerja pegawai sehari-hari

3) Komitmen pegawai terhadap tanggungjawabnya juga kurang tertuang dari kegiatan sehari-hari dalam melaksanakannya. 


\subsection{Rumusan Masalah}

Setiap lembaga atau instanasi pasti mempunyai masalah yang berbeda-beda dengan lembaga lainnya. Adanya perubahan yang selalu dihadapi oleh setiap organisasi baik yang berada diluar maupun didalam organisasi tersebut dapat menjadi hambatan demi pencapaian tujuan yang efektif dan efisien.

Berdasarkan latar belakang masalah tersebut diatas, maka yang menjadi rumusan masalah dalam penelitian ini adalah:

1) Apakah penempatan pegawai secara parsial berpengaruh positif dan signifikan terhadap motivasi kerja pegawai Badan Pengelola Keuangan, Pendapatan dan Aset Daerah Kota Tanjungbalai.

2) Apakah fasilitas secara parsial berpengaruh positif dan signifikan terhadap motivasi kerja pegawai Badan Pengelola Keuangan, Pendapatan dan Aset Daerah Kota Tanjungbalai.

3) Apakah komitmen secara parsial berpengaruh positif dan signifikan terhadap motivasi kerja pegawai Badan Pengelola Keuangan, Pendapatan dan Aset Daerah Kota Tanjungbalai.

4) Apakah penempatan pegawai, fasilitas, dan komitmen secara simultan berpengaruh positif dan signifikan terhadap motivasi kerja pegawai Badan Pengelola Keuangan, Pendapatan dan Aset Daerah Kota Tanjungbalai.

\subsection{Batasan Masalah}

Agar permasalahan yang dikaji terarah maka permasalahan dibatasi sebagai berikut. Penelitian ini akan mengkaji motivasi kerja pegawai namun dalam penelitian ini hanya membahas Pengaruh penempatan pegawai, fasilitas, dan komitmen yang berdampak ataupun tidak berdampak terhadap Motivasi kerja pegawai Badan Pengelola Keuangan, Pendapatan dan Aset Daerah Kota Tanjungbalai.

\subsection{Hioptesis}

Berdasarkan yang telah dikemukakan diatas, maka rumusan hipotesis penelitian ini dapat dirumuskan sebagai berikut:

1) Penempatan pegawai secara parsial berpengaruh positif dan signifikan terhadap motivasi kerja pegawai Badan Pengelola Keuangan, Pendapatan dan Aset Daerah Kota Tanjungbalai.
2) Fasilitas secara parsial berpengaruh positif dan signifikan terhadap motivasi kerja pegawai Badan Pengelola Keuangan, Pendapatan dan Aset Daerah Kota Tanjungbalai.

3) Komitmen secara parsial berpengaruh positif dan signifikan terhadap motivasi kerja pegawai Badan Pengelola Keuangan, Pendapatan dan Aset Daerah Kota Tanjungbalai.

4) Penempatan pegawai, fasilitas dan komitmen secara simultan berpengaruh positif dan signifikan terhadap motivasi kerja pegawai Badan Pengelola Keuangan, Pendapatan dan Aset Daerah Kota Tanjungbalai.

\subsection{Tujuan Penelitian}

Penelitian ini bertujuan untuk mengetahui dan menganalisis pengaruh penempatan pegawai, fasilitas dan komitmen terhadap motivasi kerja pegawai Badan Pengelola Keuangan, Pendapatan dan Aset Daerah Kota Tanjungbalai baik secara simultan maupun parsial, serta mencari hubungan atau pengaruh setiap variabel seperti:

1) Untuk mengetahui pengaruh penempatan pegawai terhadap motivasi kerja pegawai Badan Pengelola Keuangan, Pendapatan dan Aset Daerah Kota Tanjungbalai.

2) Untuk mengetahui pengaruh fasilitas terhadap motivasi kerja pegawai Badan Pengelola Keuangan, Pendapatan dan Aset Daerah Kota Tanjungbalai.

3) Untuk mengetahui pengaruh komitmen terhadap motivasi kerja pegawai Badan Pengelola Keuangan, Pendapatan dan Aset Daerah Kota Tanjungbalai.

4) Untuk mengetahui pengaruh penempatan pegawai, fasilitas dan komitmen terhadap motivasi kerja pegawai Badan Pengelola Keuangan, Pendapatan dan Aset Daerah Kota Tanjungbalai.

\section{Metode Penelitian}

\subsection{Populasi}

Populasi adalah sekumpulan objek yang menjadi pusat perhatian, yang padanya terkandung informasi yang ingin diketahui. Objek ini disebut dengan satuan analisis. Satuan analisis ini memiliki kesamaan perilaku atau karakteristik yang ingin diteliti. Menurut Arikunto (2013: 173) populasi adalah keseluruhan dari subjek penelitian. Jadi yang dimaksud populasi adalah individu yang 
memiliki sifat yang sama walaupun prosentase kesamaan itu sedikit, atau dengan kata lain seluruh individu yang akan dijadikan sebagai obyek penelitian. Sedangkan Sugiyono (2013: 117) populasi adalah generalisasi yang terdiri atas obyek/ subyek yang mempunyai kualitas dan karakteristik tertentu yang ditetapkan oleh peneliti untuk dipelajari dan kemudian ditarik kesimpulannya.

Maka yang menjadi populasi dalam penelitian ini adalah seluruh pegawai Badan Pengelola Keuangan, Pendapatan dan Aset Daerah Kota Tanjungbalai yang berjumlah 48 orang dengan rincian sebagai berikut:

Tabel 1. Kerangka Populasi

\begin{tabular}{|l|l|r|}
\hline No & Golongan & Jumlah \\
\hline 1 & Pembina & 5 \\
\hline 2 & Penata & 32 \\
\hline 3 & Pengatur & 10 \\
\hline 4 & Juru Muda & 1 \\
\hline \multicolumn{2}{|l|}{ Total } & $\mathbf{4 8}$ \\
\hline
\end{tabular}

Sumber: Badan Pengelola Keuangan, Pendapatan dan Aset Daerah Kota Tanjungbalai -2020

\subsection{Sampel}

Sampel merupakan contoh atau himpunan bagian (subset) dari suatu populasi yang dianggap mewakili populasi tersebut sehingga informasi apa pun yang dihasilkan oleh sampel ini bisa dianggap mewakili keseluruhan populasi. Arikunto (2013: 174) berpendapat bahwa sampel adalah sebagian atau wakil populasi yang diteliti. Sedangkan menurut Sugiyono (2013: 118) sampel adalah bagian dari jumlah dan karakteristik yang dimiliki oleh populasi tersebut.

Teknik pengambilan sampel merupakan sebuah proses penyeleksian jumlah dari populasi untuk dapat mewakili populasi. Teknik pengambilan sampel adalah berbagai cara yang ditempuh untuk pengambilan sampel agar mendapatkan sampel yang benar-benar sesuai dengan seluruh subjek penelitian tersebut (Nursalam, 2013: 113).

Pengambilan sampel dalam penelitian ini adalah dengan cara Non Probabilty Sampel atau pengambilan sampel tidak Random mengingat keterbatasan jumlah populasi pada objek peneltian. Teknik pengambilan sampel pada penelitian ini adalah total sampling. Total sampling adalah teknik pengambilan sampel dimana jumlah sampel sama dengan populasi (Sugiyono, 2013: 76). Alasan mengambil total sampling karena menurut Sugiyono (2013: 77) jumlah populasi yang kurang dari 100, seluruh populasi dijadikan sampel penelitian semuanya.

Berkaitan dengan judul penelitian yang diambil, maka sampel dalam penelitian ini adalah seluruh pegawai Badan Pengelola Keuangan, Pendapatan dan Aset Daerah Kota Tanjungbalai yang berjumlah 46 orang dengan rincian sebagai berikut:

Tabel 2. Kerangka Sampel

\begin{tabular}{|l|l|c|c|l|}
\hline No & Golongan & Populasi & Sampel & Keterangan \\
\hline 1 & Pembina & 5 & 4 & 1 Orang Merupakan Pimpinan \\
\hline 2 & Penata & 32 & 31 & 1 Orang Merupakan Peneliti \\
\hline 3 & Pengatur & 10 & 10 & - \\
\hline 4 & Juru Muda & 1 & 1 & - \\
\hline \multicolumn{2}{l}{ Total } & $\mathbf{4 8}$ & $\mathbf{4 6}$ & \\
\hline
\end{tabular}

Sumber: Badan Pengelola Keuangan, Pendapatan dan Aset Daerah Kota Tanjungbalai -2020

\subsection{Uji Normalitas}

Pengujian normalitas data bertujuan untuk melihat normal tidaknya sebaran data yang akan dianalisis. Model regresi yang baik adalah distribusi normal atau mendekati normal. Untuk melihat normalitas data ini digunakan pendekatan grafik yaitu Normality Probability Plot.

Deteksi normalitas dengan melihat penyebaran data (titik) pada sumbu diagonal dari grafik. Menurut Sugiyono (2013: 354), dasar pengambilan keputusan adalah:

a. Jika data menyebar disekitar garis diagonal dan mengikuti arah garis diagonal, maka model regresi memenuhi asumsi normalitas. b. Jika data menyebar jauh dari garis diagonal dan atau tidak mengikuti arah garis diagonal, maka model regresi tidak memenuhi asumsi normalitas.

Pada output SPSS bagian normal P-P Plot of Regresion Standardized Residual, dapat dijelaskan bahwa data-data (titik-titik) cenderung lurus mengikuti garis diagonal sehingga data dalam penelitian ini cenderung berdistribusi normal, seperti terlihat pada gambar dibawah ini. 


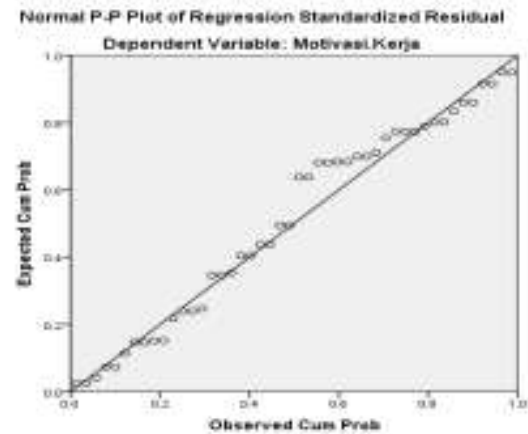

Gambar 1. Normalitas Data

Sumber: Out Put SPSS Data Diolah-2020

\subsection{Uji Multikolinearitas}

Pengujian multikolinearitas dilakukan untuk melihat apakah pada model regresi

Tabel 3. Uji Multikolinearitas

\section{Coefficients $^{\mathrm{a}}$}

\begin{tabular}{|c|c|c|}
\hline \multirow{2}{*}{ Model } & \multicolumn{2}{|c|}{ Collinearity Statistics } \\
\hline & Tolerance & VIF \\
\hline \multirow{4}{*}{$\begin{array}{l}\text { (Constant) } \\
\text { Penempatan.Pegawai } \\
\text { Fasilitas } \\
\text { Komitmen }\end{array}$} & & \\
\hline & .833 & 1.201 \\
\hline & .920 & 1.087 \\
\hline & .824 & 1.214 \\
\hline
\end{tabular}

\subsection{Uji Heteroskedastisitas}

Pengujian heteroskedastisitas bertujuan untuk melihat apakah dalam sebuah model regresi terjadi ketidaksamaan varians dari residual yang merupakan suatu pengamatan ke pengamatan yang lainnya. Jika varians dari residual yang merupakan suatu pengamatan ke pengamatan yang lain bernilai tetap, maka hasil data disebut homoskedastisitas dan jika varians berbeda atau bernilai tidak tetap maka disebut heteroskedastisitas. Model regresi yang baik adalah model yang bernilai tetap atau homoskedastisitas atau tidak terjadi heteroskedastisitas.

Deteksi heteroskedastisitas dilakukan dengan cara melihat ada tidaknya pola tertentu pada data yang diolah. Menurut Sugiyono (2013: 354), dasar pengambilan keputusannya adalah:

a. Jika pola tertentu seperti titik-titik yang ada membentuk suatu pola tertentu yang teratur, maka terdapat situasi heteroskedastisitas.

b. Jika tidak ada pola yang jelas, serta titik-titik menyebar diatas dan dibawah angka nol pada sumbu Y, maka tidak terjadi heteroskedastisitas. ditemukan adanya korelasi antara variabel bebas. Jika terjadi korelasi, maka dinamakan terdapat problem multikolinearitas. Cara mendeteksinya adalah dengan melihat nilai Variance Inflation Factor (VIF). Menurut lebih besar dari 5 , maka variabel bebas tersebut mempunyai persoalan multikolinearitas dengan variabel bebas lainnya.

Pada ouput SPSS bagian Coefficient, semua angka VIF berada dibawah 5, hal ini menunjukan tidak terjadi multikolinearitas, seperti dapat dilihat pada tabel dibawah ini. Sugiyono (2013: 354), pada umumnya jika VIF

Pada output SPSS dibagian Scatrerplot, terlihat titk-titik menyebar secara acak, tidak membentuk sebuah pola tertentu yang jelas, serta tersebar baik diatas maupun dibawah angka nol pada sumbu Y. Hal ini berarti tidak terjadi hetorskedastisitas pada model regresi, sehingga model regresi layak dipakai. Pola Scatterplot dapat dilihat pada gambar dibawah ini.

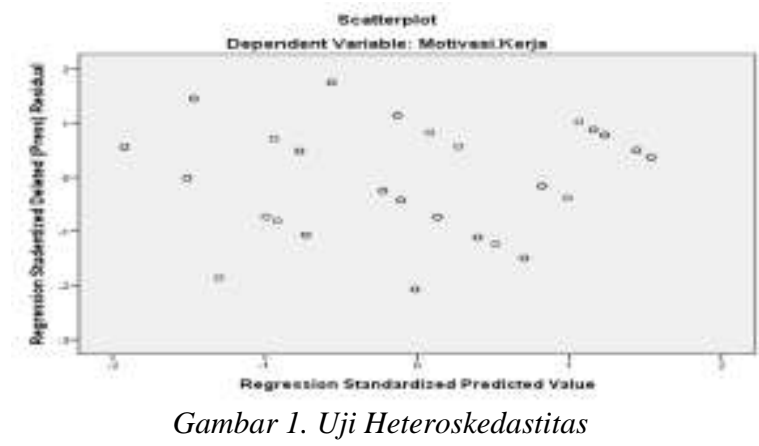

\section{Hasil dan pembahasan \\ 3.1. Hasil Regresi Linear Berganda}

Hasil regresi linear berganda di peroleh sebagai berikut : 
Tabel 4. Hasil Uji Statistik Keofesien Regresi

\begin{tabular}{|c|c|c|c|c|c|c|}
\hline \multirow{2}{*}{\multicolumn{2}{|c|}{ Model }} & \multicolumn{2}{|c|}{$\begin{array}{l}\text { Unstandardized } \\
\text { Coefficients }\end{array}$} & $\begin{array}{l}\text { Standardized } \\
\text { Coefficients }\end{array}$ & \multirow[t]{2}{*}{$\mathrm{t}$} & \multirow[t]{2}{*}{ Sig. } \\
\hline & & $\mathrm{B}$ & Std. Error & Beta & & \\
\hline \multirow{4}{*}{1} & (Constant) & 6.857 & 4.693 & & 1.461 & .151 \\
\hline & Penempatan.Pegawai & .238 & .088 & .272 & 2.693 & .010 \\
\hline & Fasilitas & .257 & .080 & .306 & 3.191 & .003 \\
\hline & Komitmen & .408 & .082 & .507 & 4.994 & .000 \\
\hline
\end{tabular}

Berdasarkan tabel 4 diatas dapat dibuat persamaan regresi sebagai berikut:

$Y=6,857+0,238 X_{1}+0,257 X_{2}+0,408 X_{3}+\varepsilon$

Persamaan diatas dijelaskan bahwa koefesien $\mathrm{X}_{1} \quad$ (penempatan pegawai) mempunyai nilai positif yaitu 0.238 , hal ini menunujukan bahwa variabel penempatan pegawai mempunyai pengaruh positif terhadap motivasi kerja pegawai. Jika penempatan pegawai yang selalu diperhatikan terhadap pegawai maka akan berdampak positif terhadap motivasi kerja pegawai Badan Pengelola Keuangan, Pendapatan dan Aset Daerah Kota Tanjungbalai.

Berdasarkan persamaan diatas bahwa koefesien $\mathrm{X}_{2}$ (fasilitas) juga memiliki nilai positif yaitu 0,257 . Hal ini menunjukan bahwa variabel fasilitas mempunyai pengaruh positif terhadap motivasi kerja pegawai.
Berdasarkan persamaan diatas bahwa koefesien $\mathrm{X}_{3}$ (komitmen) juga memiliki nilai positif yaitu 0,408 . Hal ini menunjukan bahwa variabel komitmen mempunyai pengaruh positif terhadap motivasi kerja pegawai.

Hal ini berarti jika seorang pemimpin didalam organisasinya memperhatikan bagaimana penempatan pegawai pegawainya, fasilitas yang diberikan serta komitmen setiap pegawai dalam pekerjaannya maka akan berdampak positif terhadap motivasi kerja pegawai di Badan Pengelola Keuangan, Pendapatan dan Aset Daerah Kota Tanjungbalai.

\subsubsection{Pengujian Secara Simultan (Uji F)}

Hasil pengujian hipotesis pengaruh penempatan pegawai, fasilitas dan komitmen terhadap motivasi kerja pegawai dapat dilihat pada tabel dibawah ini.

Tabel 5. Hasil Uji Statistik Secara Simultan

\begin{tabular}{|c|c|c|c|c|c|}
\hline Model & Sum of Squares & $\overline{\mathrm{df}}$ & Mean Square & $\bar{F}$ & Sig. \\
\hline Regression & 36.540 & 3 & 12.180 & 25.353 & $.000^{\mathrm{b}}$ \\
\hline Residual & 20.178 & 42 & .480 & & \\
\hline Total & 56.717 & 45 & & & \\
\hline
\end{tabular}

a. Dependent Variable: Motivasi.Kerja

b. Predictors: (Constant), Komitmen, Fasilitas, Penempatan.Pegawai

Pada tabel 5. diatas terlihat bahwa nilai $\mathrm{F}_{\text {hitung }}$ adalah 25,353 dan nilai signifikansi $0,000^{\mathrm{b}}$. Diketahui nilai $\mathrm{F}_{\text {tabel }}$ dengan tingkat kepercayaan 95\% $(\alpha: 0,05)$ adalah 2,810 . Oleh karena itu nilai $F_{\text {hitung }}>F_{\text {tabel }}(25,353>2,810)$ maka $\mathrm{H}_{\mathrm{o}}$ ditolak dan menerima $\mathrm{H}_{\mathrm{a}}$ hipotesis dalam penelitian ini yaitu bahwa penempatan pegawai, fasilitas dan komitmen secara simultan berpengaruh positif dan signifikan terhadap motivasi kerja pegawai Badan Pengelola Keuangan, Pendapatan Dan Aset Daerah Kota Tanjungbalai. 


\subsubsection{Pengujian Secara Parsial (Uji t)}

a. Pengaruh Penempatan pegawai Terhadap Motivasi kerja Pegawai

Tabel 6. Hasil Uji Parsial Variabel $\mathrm{X}_{1}$ Terhadap Y

\begin{tabular}{|c|l|l|l|l|l|}
\hline \multirow{2}{*}{ Model } & \multicolumn{2}{|l|}{$\begin{array}{l}\text { Unstandardized } \\
\text { Coefficients }\end{array}$} & $\begin{array}{l}\text { Standardized } \\
\text { Coefficients }\end{array}$ & t & \multirow{2}{*}{ Sig. } \\
\cline { 2 - 4 } & $\mathrm{B}$ & Std. Error & Beta & \\
\hline $\begin{array}{c}\text { Penempatan. } \\
\text { Pegawai }\end{array}$ & .238 & .088 & .272 & 2.693 & .010 \\
\hline
\end{tabular}

Sumber: Out Put SPSS Data Diolah-2020

Untuk mengetahui secara partial pengaruh penempatan pegawai terhadap motivasi kerja pegawai dapat dilihat pada tabel 6 diatas. Berdasarkan tabel tersebut diperoleh nilai $t_{\text {hitung }}$ sebesar 2,693 dan nilai signifikansi 0,010 . Sedangkan nilai $\mathrm{t}_{\text {tabel }}$ pada tingkat kepercayaan $95 \%(\alpha: 0,05)$ adalah 2,021. Oleh karena itu nilai $\mathrm{t}_{\text {hitung }}>\mathrm{t}_{\text {tabel }}(2,693>2,021)$ maka $\mathrm{H}_{\mathrm{o}}$ ditolak dan menerima $\mathrm{H}_{\mathrm{a}}$ hipotesis dalam penelitian ini yaitu variabel penempatan pegawai secara parsial berpengaruh positif dan signifikan terhadap motivasi kerja pegawai Badan Pengelola Keuangan, Pendapatan Dan Aset Daerah Kota Tanjungbalai.

\section{b. Pengaruh Fasilitas Terhadap Motivasi kerja Pegawai}

Tabel 7. Hasil Uji Parsial Variabel $\mathrm{X}_{2}$ Terhadap Y

\begin{tabular}{|c|l|l|l|l|l|}
\hline \multirow{2}{*}{ Model } & \multicolumn{2}{|l|}{$\begin{array}{l}\text { Unstandardized } \\
\text { Coefficients }\end{array}$} & $\begin{array}{l}\text { Standardized } \\
\text { Coefficients }\end{array}$ & $\mathrm{t}$ & \multirow{2}{*}{ Sig. } \\
\cline { 2 - 5 } & $\mathrm{B}$ & Std. Error & Beta & & \\
\hline Fasilitas & .257 & .080 & .306 & 3.191 & .003 \\
\hline
\end{tabular}

Sumber: Out Put SPSS Data Diolah-2020

Untuk mengetahui secara partial pengaruh fasilitas terhadap motivasi kerja pegawai dapat dilihat pada tabel 5.16 diatas. Berdasarkan tabel tersebut diperoleh nilai $t_{\text {hitung }}$ sebesar 3,191 dan nilai signifikansi 0,003 . Sedangkan nilai $t_{\text {tabel }}$ pada tingkat kepercayaan $95 \%(\alpha: 0,05)$ adalah 2,021 . Oleh karena itu nilai $t_{\text {hitung }}>t_{\text {tabel }}(3,191>$
2,021) maka $\mathrm{H}_{\mathrm{o}}$ ditolak dan menerima $\mathrm{H}_{\mathrm{a}}$ hipotesis dalam penelitian ini yaitu variabel fasilitas secara parsial berpengaruh positif dan signifikan terhadap motivasi kerja pegawai Badan Pengelola Keuangan, Pendapatan Dan Aset Daerah Kota Tanjungbalai.

\section{c. Pengaruh Komitmen Terhadap Motivasi kerja Pegawai}

Tabel 8. Hasil Uji Parsial Variabel $\mathrm{X}_{3}$ Terhadap $\mathrm{Y}$

\begin{tabular}{|c|l|l|l|l|l|}
\hline \multirow{2}{*}{ Model } & \multicolumn{2}{|l|}{$\begin{array}{l}\text { Unstandardized } \\
\text { Coefficients }\end{array}$} & $\begin{array}{l}\text { Standardized } \\
\text { Coefficients }\end{array}$ & & \multirow{2}{*}{ Sig. } \\
\cline { 2 - 5 } & B & Std. Error & Beta & & \\
\hline Komitmen & .408 & .082 & .507 & 4.994 & .000 \\
\hline
\end{tabular}

Sumber: Out Put SPSS Data Diolah-2020

Untuk mengetahui secara partial pengaruh komitmen terhadap motivasi kerja pegawai dapat dilihat pada tabel 8 diatas. Berdasarkan tabel tersebut diperoleh nilai $t_{\text {hitung }}$ sebesar 4,994 dan nilai signifikansi 0,000 . Sedangkan nilai $\mathrm{t}_{\text {tabel }}$ pada tingkat kepercayaan $95 \%(\alpha: 0,05)$ adalah 2,021. Oleh karena itu nilai $t_{\text {hitung }}>t_{\text {tabel }}$ (4,994 > 2,021) maka $\mathrm{H}_{\mathrm{o}}$ ditolak dan menerima $\mathrm{H}_{\mathrm{a}}$ hipotesis dalam penelitian ini yaitu variabel komitmen secara parsial berpengaruh positif dan signifikan terhadap motivasi kerja pegawai
Badan Pengelola Keuangan, Pendapatan Dan Aset Daerah Kota Tanjungbalai.

\subsection{Uji Koefisien Determinasi $\left(\mathbf{R}^{2}\right)$}

Uji determinan adalah untuk mengetahui seberapa besar pengaruh variabel independent terhadap variabel dependent. Untuk melihat hasil uji determinan maka dapat diketahui nili $\mathrm{R}$ Square atau koefesien determinasi dan dapat dilihat dibawah ini. 
Tabel 9 Model Summary

\begin{tabular}{|l|r|r|r|r|}
\hline Model & \multicolumn{1}{|c|}{$\mathrm{R}$} & \multicolumn{1}{c|}{ R Square } & Adjusted R Square & Std. Error of the Estimate \\
\hline 1 & $.803^{\mathrm{a}}$ & .644 & .619 & .693 \\
\hline
\end{tabular}

Sumber: Out Put SPSS Data Diolah-2020

Nilai R Square pada tabel diatas adalah 0,644. Hal ini menunjukan bahwa $64,4 \%$ variabel motivasi kerja pegawai Badan Pengelola Keuangan, Pendapatan dan Aset Daerah Kota Tanjungbalai dijelaskan oleh variabel penempatan pegawai, fasilitas dan komitmen, sedangkan sisanya sebesar $35,6 \%$ tidak dilakukan penelitian.

\section{Kesimpulan}

Dari hasil penelitian diatas maka dapat diambil kesimpulan sebagai berikut :

1) Penempatan pegawai secara parsial berpengaruh positif dan signifikan terhadap motivasi kerja pegawai Badan Pengelola Keuangan, Pendapatan Dan Aset Daerah Kota Tanjungbalai.

2) Fasilitas secara parsial berpengaruh positif dan signifikan terhadap motivasi kerja pegawai Badan Pengelola Keuangan, Pendapatan Dan Aset Daerah Kota Tanjungbalai.

3) Komitmen secara parsial berpengaruh positif dan signifikan terhadap motivasi kerja pegawai Badan Pengelola Keuangan, Pendapatan Dan Aset Daerah Kota Tanjungbalai.

4) Penempatan pegawai, fasilitas dan komitmen secara simultan berpengaruh positif dan signifikan terhadap motivasi kerja pegawai Badan Pengelola Keuangan, Pendapatan Dan Aset Daerah Kota Tanjungbalai.

5) Nilai R Square pada hasil penelitian ini adalah 0,644. Hal ini menunjukan bahwa $64,4 \%$ variabel motivasi kerja pegawai Badan Pengelola Keuangan, Pendapatan dan Aset Daerah Kota Tanjungbalai dijelaskan oleh variabel penempatan pegawai, fasilitas dan komitmen, sedangkan sisanya sebesar $35,6 \%$ tidak dilakukan penelitian.

\section{DAFTAR PUSTAKA}

Ahmad Ibrahim Abu Sinn (2018). Manajemen Syariah. Jakarta: Raja Grafindo Persada.
Alwi, S (2011). Manajemen Sumber Daya Manusia, Strategi Keunggulan Kompetitif. Yogyakarta: BPFE.

Arikunto, S (2016). Prosedur Penelitian Suatu Pendekatan Praktik. Jakarta: Rineka Cipta.

Batubara, Enri Cofermi (2010). Hubungan Komitmen Terhadap Tugas ,Pemberian Imbalan dan Motivasi Kerja Dengan Disiplin Kerja Guru SMA SeKabupaten Madina, EducanduM.Jurnal Manajemen Pendidikan. Program Doktor Manajemen Pendidikan Pascasarjana Universitas Negeri Medan, Vol.III, No.02 :

Byron, William J (2010). The Power Of Principle, Etika untuk Budaya Baru Perusahaan. Yogyakarta: Kanisius.

Chukwuma, E.M., \& Obiefuna, O. (2014). Effect of Motivation on Employee Productivity : A Study of Manufacturing Companies in Nnewi.Journal of Managerial Studies and Research .

Damayanti, K dan Suhariadi (2013). Hubungan Antara Persepsi Terhadap Keadilan Organisasi Dengan Komitmen. Surabaya: Media Psikologi.

Danim, S (2014). Motivasi, Kepemimpinan, dan Efektivitas Kelompok, 11, 15, 18, 46. Jakarta: Rineka Cipta.

Djoyowirono, Sugeng (2015). Manajemen Konstruksi.Edisi Keempat Yogyakarta: KMTS FT, UGM.

Gaol, CHR. Jimmy L (2014). A to Z Human Capital (Manajemen Sumber Daya Manusia) Konsep, Teori, dan Pengembangan dalam Konteks Organisasi Publik dan Bisnis. Jakarta: Gramedia Widiasarana Indonesia.

Ghozali, Imam (2016). Aplikasi Analisis Multivariete Dengan Program. IBM SPSS 23. Semarang: Badan Penerbit.

Handoko T. Tani (2013). Manajemen Personalia dan Sumber Daya Manusia.Edisi kedua Yogyakarta: BPPE. 
Husnan, Suad (2012). Manajemen Personalia.Edisi Keempat Yogyakarta: BPFE.

Iskandar (2018). Metodologi Penelitian Pendidikan dan Sosial (Kuantitatif dan. Kualitatif). Jakarta: Raja Grafindo Persada.

Junaidah Hashim Yusof Ismail (2017). Establishing linkages between religiosity and spirituality on employee performance.The International Journal of Human Resource Management, 35 (4), 360-376. : .

Lupiyaodi (2016). Manajemen Pemasaran Jasa.Edisi Kedua, Jakarta: Salemba Empat

Luthans, Fred (2016). Perilaku Organisasi. Yogyakarta: Andi.

Mangkuprawira (2011). Manajemen Sumber Daya Manusia Strategik. Bogor: Ghalia Indonesia.

Marihot Tua Efendi Hariandja (2012). Manajeman Sumber Daya Manusia. Jakarta: Gramedia Widiasarana Indonesia.

Martini, Y (2013). Komitmen Organisasi Ditinjau dari Iklim Organisasi dan Motivasi Berprestasi. Jakarta: Phornesis.

Miftahun, N., \& Sugiyanto (2010). Pengaruh Dukungan Sosial dan Kepemimpinan Transformasional Terhadap Komitmen Organisasi dengan Mediator Motivasi Kerja.Jurnal Psikologi Yogyakarta: FPUGM.

Nursalam (2013). Metodologi Penelitian Ilmu Penellitian. Jakarta: Salemba Medika.

Oemar Hamalik (2010). Pengembangan SDMManajemen Pelatihan Ketenagakerjaan Pendekatan Terpadu. Jakarta: Bumi Aksara.

Pamela, A.O., \& Oloko (2015). Effect of motivation on employee performance of commercial banks in kenya : A case study of Kenya Commercial Bank in Migori County.Journal of Human Resource Studies.

Rivai, Veithzal dan Sagala, Jauvani (2011). Manajemen Sumber Daya Manusia untuk Perusahaan. Jakarta: Rajagrafindo Persada.

Robbins SP (2017). Perilaku Organisasi. Jakarta: Salemba Empat.

Robbinss, Stephen P (2011). Organizational Behavior (Terjemahan) Jilid 1, Edisi Kedelapan. Jakarta: Bhuana Ilmu Populer.
Sardiman (2017). Interaksi dan Motivasi. Jakarta: Rajagrafindo Persada.

Sastrohadiwiryo, Siswanto (2013). Manajemen Tenaga Kerja Indonesia. Jakarta: Bumi Aksara.

Sihite, M (2017). Pengaruh Kepuasan Kerja dan Komitmen Organisasi terhadap Kinerja Dosen Politeknik Mandiri Bina Prestasi Medan. Medan: SPUSU.

Siswanto (2012). Pengantar Manajemen. Jakarta: Bumi Aksara.

Sopiah (2018). Perilaku Organisasi. Yogyakarta: Andi Offset.

Sugiyono (2012). Metode Penelitian Kuantitatif Kualitatif dan $R \& D$. Bandung: Alfabeta.

Suwarto (2010). Perilaku Keorganisasian. Yogyakarta: Universitas Atma Jaya.

Swastha dan Ibnu Sukotjo W (2014). Pengantar Bisnis Modern.Cetakan Kedelapan Yogyakarta: Liberty.

Yuniarsih, T., \& Suwatno, (2013). Manajemen Sumber Daya Manusia Teori, Aplikasi dan isu penelitian. Bandung: Alfabeta. 